\title{
EB Virus Antibody at Different Ages
}

\author{
MARGUERITE S. PEREIRA,* M.D. ; JEAN M. BLAKE, $†$ B.SC. ; A. D. MACRAE, $\ddagger$ M.D., F.C.PATh.
}

Summary : In relation to the study of infectious mono$S$ nucleosis a survey of the prevalence of antibody to EB virus was made on the sera of persons of varying age from several different areas in England by the indirect immunofluorescence technique. About half those tested were found to have acquired antibody by the age of 4 years and there was a further significant increase in the proportion of those positive between the ages of 15 and 24 years. The finding of seroconversion in two patients who developed infectious mononucleosis provides further support for an association between EB virus and this condition.

\section{Introduction}

The establishment of continuous cultures of lymphoblasts from Burkitt's lymphoma biopsies (Epstein and Barr, 1964) was followed by the observation (Epstein et al., 1964) that in some of these cultures a proportion of the cells carried a herpes-like virus. This virus has been called EB virus after the cell strains in which it was found. Cultivation of EB virus in other cells has not so far been found possible. Serological studies have depended mainly on techniques such as direct or indirect immunofluorescence, the antibody reacting specifically with the cells which contain virus. By the indirect immunofluorescence test antibody has been found in the serum of all patients with Burkitt's lymphoma and also in a considerable proportion of other persons of all age groups. In the course of studies of this phenomenon Henle et al. (1968) found a significant correlation between the development of $\mathrm{EB}$ virus antibody and infectious mononucleosis, which suggested that EB virus was one aetiological agent in this disease.

In its typical form infectious mononucleosis affects young adults, often among the higher socioeconomic groups. Multiple cases among contacts are not commonly found. The heterophil antibody Paul-Bunnell test becomes positive early in the disease but usually reverts to negative in a short time. There is little information on the incidence of the disease generally, the diagnosis being restricted to patients on whom laboratory investigations including a Paul-Bunnell test have been done.

With the information now available on $\mathrm{EB}$ virus it has become possible to determine the proportion of people already infected with this virus and having antibody to it. This may help to explain the epidemiological pattern of infectious mononucleosis.

This report gives the results, determined by indirect immunofluorescence, of $\mathrm{EB}$ virus antibody tests on sera from persons of different ages in England.

\section{Serum Samples}

\section{Materials}

Two groups of sera were examined.

Group A from persons with some form of illness. (1) A miscellaneous group of 335 children and adults up to 40 years of age whose sera had been submitted initially for antistrepto-

* Deputy Director

Deputy Director.

† Scientific

F Director. N.W.9. lysin $\mathrm{O}$ estimation. (2) 66 children admitted to hospital in London with respiratory illness. Of these, 11 were samples taken during the acute stage of illness only, 39 were paired acute and convalescent samples, and 16 were samples taken during convalescence only.

Group B from healthy persons. (3) 135 children attending day nurseries in London and primary schools in north-west England. These were kindly provided by Dr. D. Reid. (4) 123 young adults at a teachers' training college in Middlesex. These were kindly provided by Dr. S. G. Lamb.

\section{Methods}

EB3 cells kindly supplied by Professor M. A. Epstein were cultivated on Eagle's basal medium supplemented with $10 \%$ fetal calf serum.

For the tests, after preliminary incubation for three to four days in arginine-free Eagle's medium containing $25 \%$ fetal calf serum, drops of a concentrated cell suspension were placed on coverslips, dried at $37^{\circ} \mathrm{C}$., fixed in acetone for 10 minutes, and stored frozen at $-20^{\circ} \mathrm{C}$. until required. Sera were inactivated at $56^{\circ} \mathrm{C}$. for 30 minutes. The main antibody survey was done with a single $1 / 5$ dilution of each serum. Positive and negative control sera were included in each test. A minimum of 8 cells showing bright green fluorescence was obtained in every field with the positive serum and none with the negative serum. Goat anti-human IgG conjugate (Hyland Laboratories) was used.

\section{Results}

The results of tests with antistreptolysin $\mathrm{O}$ sera are shown in Table I. The number of children under 4 in this group was small, but antibody was found in more than $50 \%$. In the next age group the proportion was less, but in the 15-24 age group it was higher and increased steadily as the age rose. No sex difference was observed.

\begin{tabular}{c|c|c|c|c|c|c}
\multicolumn{3}{c}{ TABLE I.-EB Virus Antibody in Antistreptolysin O Sera } \\
\hline $\begin{array}{c}\text { Age } \\
\text { Group }\end{array}$ & \multicolumn{3}{|c|}{ No. of Sera Tested } & \multicolumn{3}{|c}{$\%$ \%ositive } \\
\cline { 2 - 7 } (Years) & Male & Female & Both & Male & Female & Both \\
\hline $0-4$ & 12 & 9 & 21 & 50 & 67 & 57 \\
$5-14$ & 61 & 40 & 101 & 39 & 38 & 39 \\
$15-24$ & 38 & 53 & 91 & 84 & 79 & 81 \\
$25-34$ & 28 & 48 & 76 & 82 & 83 & 83 \\
$35-40$ & 20 & 28 & 48 & 90 & 89 & 90 \\
\hline
\end{tabular}

Table II gives the results on sera from children in hospital.

TABLE II.-EB Virus Antibody in Sera from Children in Hospital with TABLE 1I.-EB Virus Antibody intory Ilnesses
Respiration

\begin{tabular}{c|c|c}
\hline Age Group (Years) & No. of Sera Tested & No. Positive \\
\hline $0-4$ & 44 & $15(34 \%)$ \\
$5-14$ & 22 & $10(45 \%)$
\end{tabular}

Here the proportion of children under 4 who were positive was lower, but among those 5-14 years of age it was slightly higher. Among the paired samples of serum tested none showed conversion from negative to positive. Examination of the results showed that 8 out of 19 patients with a febrile sore throat but only 1 out of 12 patients diagnosed as cases of 
febrile catarrh had EB antibody in their serum. The significance of these findings is uncertain, but further study is needed.

Table III gives the results on sera from students of both sexes at a teachers' training college. Among these the proportion with antibody was lower than was found in the equivalent age groups shown in Table I. In the youngest group about $40 \%$ still lacked antibody.

TABLE III.-EB Antibody in Sera from New Students at a Teachers' Training College

\begin{tabular}{c|c|c} 
Age Group (Years) & No. Tested & No. Positive \\
\hline $18-24$ & 85 & $50(59 \%)$ \\
$25-34$ & 16 & $11(69 \%)$ \\
$35-49$ & 22 & $16(73 \%)$
\end{tabular}

Table IV gives the results of tests on sera from healthy children. Those in day nurseries were aged 3-5 years and those in primary schools 4-5 years. The proportion positive from the primary schools was similar to the proportion in this age group shown in Table I. In the day nurseries, however, the proportion positive from three of these was much higher than expected.

TABLE IV.-EB Virus Antibody in Sera from Nurseries and Primary

\begin{tabular}{|c|c|c|c|}
\hline & & No. of Sera Tested & No. Positive \\
\hline $\begin{array}{l}\text { Nursery } 1 \\
\text { Nursery } 2 \\
\text { Nursery } 3 \\
\text { Nursery } 4 \\
\text { Primary school } \\
\text { Primary school } \\
\text { Primary school } \\
\text { Primary school } \\
\text { Primary school } 5 \\
\text { Primary school } 6 \\
\text { Primary school } 7\end{array}$ & 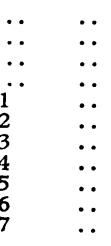 & $\begin{array}{r}9 \\
6 \\
14 \\
14 \\
23 \\
16 \\
18 \\
10 \\
7 \\
14 \\
4\end{array}$ & $\begin{array}{c}7(78 \%) \\
3(50 \%) \\
10(71 \%) \\
10(71 \%) \\
9(39 \%) \\
9(56 \%) \\
9(50 \%) \\
6(60 \%) \\
3(43 \%) \\
5(36 \%) \\
3(75 \%)\end{array}$ \\
\hline
\end{tabular}

Table $\mathrm{V}$ contains information on all the sera tested. It shows the development of EB virus antibody during childhood and a steady increase in the proportion positive with increasing age. No significant sex difference was observed.

\begin{tabular}{c|c|c|c|c|c|c}
\multicolumn{3}{c}{ TABLE V.-Overall Results of EB Virus Antibody Tests } \\
\hline $\begin{array}{c}\text { Age } \\
\text { Group }\end{array}$ & \multicolumn{3}{|c|}{ No. of Sera Tested } & \multicolumn{3}{|c}{$\%$ Positive } \\
\cline { 2 - 7 } (Years) & Male & Female & Both & Male & Female & Both \\
\hline $0-4$ & 81 & 51 & 132 & 53 & 49 & 52 \\
$5-14$ & 86 & 69 & 155 & 43 & 41 & 42 \\
$15-24$ & 47 & 129 & 176 & 72 & 70 & 70 \\
$25-34$ & 31 & 61 & 92 & 77 & 82 & 80 \\
$35-44$ & 21 & 42 & 63 & 90 & 83 & 86 \\
\hline
\end{tabular}

As well as the main investigation of $\mathrm{EB}$ virus antibody in sera, blood from patients in the acute phase of infectious mononucleosis was investigated and invariably contained EB virus antibody at the time the first sample after the onset of illness was taken. In two instances, however, conversion from a negative to a positive reaction was detected. Both patients, who were young men, had been bled for another investigation a few weeks before their illness. At that time neither had EB virus antibody in their sera, but, when they developed infectious mononucleosis, blood taken shortly after onset of illness was positive. Serial samples of blood were obtained from one patient and the results of both the EB virus and the PaulBunnell titrations are set out in Table VI, the latter were kindly provided by Dr. A. M. R. Mackenzie. Both tests were positive soon after the illness developed, but the $\mathrm{EB}$ virus antibody increased in titre more slowly and reached its peak at a time when the Paul-Bunnell test had reverted to negative.

\section{Discussion}

In the sera examined EB virus antibody has been found to be widespread. There is considerable variation in the proportion positive among persons of the same age in the different groups, so that environment may also be a factor (Henle et al., 1968 ; Porter et al., 1969).
TABLE VI.-Results of Tests on Serial Samples of Serum from One Patient*

\begin{tabular}{|c|c|c|c|c|c|}
\hline \multirow[b]{2}{*}{ Serum } & \multirow[b]{2}{*}{ Date } & \multirow[b]{2}{*}{$\begin{array}{l}\text { EB Virus } \\
\text { Antibody } \\
\text { Titre }\end{array}$} & \multicolumn{3}{|c|}{ Paul-Bunnell Titre } \\
\hline & & & Unabsorbed & $\begin{array}{c}\text { After } \\
\text { Absorption } \\
\text { with } \\
\text { Guinea-pig } \\
\text { Kidney }\end{array}$ & $\begin{array}{c}\text { After } \\
\text { Absorption } \\
\text { with Ox } \\
\text { Red Blood } \\
\text { Cells }\end{array}$ \\
\hline $\begin{array}{r}1 \\
2 \\
3 \\
4 \\
5 \\
6 \\
7 \\
8 \\
9 \\
10 \\
11 \\
12\end{array}$ & $\begin{array}{c}19 / 11 / 68 \\
4 / 12 / 68 \\
21 / 12 / 68 \\
27 / 12 / 68 \\
16 / 1 / 69 \\
30 / 1 / 69 \\
11 / 2 / 69 \\
18 / 2 / 69 \\
5 / 3 / 69 \\
24 / 3 / 69 \\
1 / 4 / 69 \\
28 / 5 / 69\end{array}$ & $\begin{array}{l}<1 / 5 \\
<1 / 5 \\
<1 / 8 \\
N . D . \\
1 / 40 \\
1 / 40 \\
1 / 80 \\
1 / 80 \\
1 / 80 \\
1 / 80 \\
1 / 160 \\
1 / 80\end{array}$ & $\begin{array}{l}\text { N.D. } \\
\text { N.D. } \\
\text { Neg. } \\
1 / 640 \\
1 / 160 \\
1 / 2,560 \\
1 / 1,280 \\
1 / 310 \\
1 / 160 \\
1 / 40 \\
<1 / 10 \\
\text { Neg. }\end{array}$ & $\begin{array}{l}\text { 二 } \\
\overline{1} \\
1 / 320 \\
1 / 80 \\
1 / 1,280 \\
1 / 1,280 \\
1 / 160 \\
1 / 80 \\
1 / 40 \\
<1 / 10 \\
\end{array}$ & $\begin{array}{r}\bar{Z} \\
\bar{Z} \\
<1 / 10 \\
<1 / 10 \\
1 / 40 \\
1 / 20 \\
1 / 10 \\
<1 / 10 \\
<1 / 10 \\
=\end{array}$ \\
\hline
\end{tabular}

The overall incidence of antibody corresponds well with $\frac{0}{3}$ reports from the United States (Henle and Henle, 1967 ; Deinhardt et al., 1969), where both groups found a significant is decrease in the proportion of those negative in early childhood $\infty$ and again during the late teenage and early adult years. Henle $\stackrel{N}{\mathcal{G}}$ and Henle (1967) found that, though the incidence was low in $N$ the 4-24 months' age group, about half the population had 0 antibody by the age of 4 . In our study, on subdivision of the children into these age groups the same held true in $\mathbb{O}$ England.

Porter et al. (1969), studying another group in the United $\frac{\bigcirc}{\Phi}$ States, found in children up to 2 years of age and regardless $\bar{Z}$ of their socioeconomic status that about $45 \%$ had EB virus $\mathbb{Q}$ antibody. By 4 years as many as $70 \%$ were positive, with a $\vec{\varphi}$ slightly higher prevalence in those less well off. In addition, $\mathscr{O}$ this infection appeared earlier and was more common than. infection with herpes simplex and cytomegaloviruses.

Perhaps the most striking feature of our results was the finding that over $70 \%$ of children had EB virus antibody in three out of four day nurseries. These children were 3-5 years $\frac{\odot}{\varnothing}$ of age, and that percentage is a higher than average incidence. $\varnothing$ The conditions of close and continuous contact in nurseries $\overrightarrow{\overrightarrow{0}}$ could well be a decisive factor in the spread of EB virus. In 3 this connexion a survey of an Alaskan island population by Deinhardt et al. (1969) showed that all but one individual had $\mathrm{EB}$ virus antibody.

Support for the association between EB virus and infectious mononucleosis has come from the tests on two patients in whom $\frac{\sigma}{6}$ the clinical disease was accompanied by the development of EB virus antibody. Because of the published reservations that pre- $\delta$ illness sera may not be completely devoid of EB virus antibody (Glade et al., 1969) these were rechecked undiluted and at a $ᄋ$ $1 / 2$ dilution, but were still negative. Also, in a recent report $\vec{N}$ (see Evans et al., 1969) infectious mononucleosis with clinical o and the typical heterophil response was induced in a patient $\frac{D}{0}$ with leukaemia by the injection of partially purified EB virus.

Acknowledgement is made for the help given during this $N$ investigation to Drs. Gertrude and Werner Henle, Philadelphia; $\omega$ Professor M. A. Epstein, Bristol ; Dr. S. G. Lamb, Isleworth ; Dr. F. O. MacCallum and Dr. A. M. R. Mackenzie, Oxford; Mr. G. Wilcock, Oxford, for the serial samples of serum he provided; and $\Phi$ Dr. D. Reid, Colindale. This work was supported by a grant from the National Fund for Research into Crippling Diseases.

REFERENCES

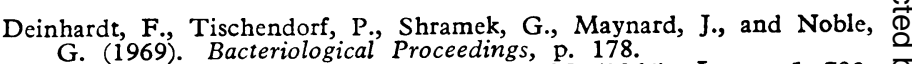

Epstein, M. A., Achong, B. G., and Barr, Y. M. (1964). Lancet, 1, 702. ర Epstein, M. A., and Barr, Y. M. (1964). Lancet, 1, 252.

Evans, A. S., Niederman, J. C., and McCollum, R. W. (1969). New 8 England Fournal of Medicine, 280, 112.

Glade, P. R., Hirshhorn, K., and Douglas, S. D. (1969). Lancet, 1, 1049

Henle, G., and Henle, W. (1967). Cancer Research, 27, 2442.

Henle, G., Henle, W., and Diehl, V. (1968). Proceedings of the National

Academy of Sciences of the United States of America, 59, 94.

Porter, D. D., Wimberly, I., and Benyesh-Melnick, M. (1969). fournal

of the American Medical Association, 208, 1675.

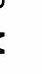

